\title{
Examination of the physical profiles of physically handicapped female badminton players
}

\author{
Mehmet Fatih YÜKSEL
}

Department Physical Education and Sport, Faculty of Education, Necmettin Erbakan University, Konya,

A part of this research was presented via poster in " $15^{\text {th }}$ International Sports Sciences Congress" in 15-18 November 2017.

Correspondence to M.F. Yüksel, e-mail; yukselmehmetfatih@gmail.com

\begin{abstract}
This research was conducted to determine physical characteristics of physically handicapped women badminton players and to examine the effects of badminton sport on the physical characteristics of physically handicapped women. A total of 43 women including physically handicapped badminton players $(n=20)$ and control group consisting of physically handicapped $(n=23)$ participated voluntarily to the researh. In accordance with the obstacle classification determined by the International Physically Handicappeds Badminton Federation, handicapped female badminton players were composed of two groups including SL-3, SL-4, SU-5 (standing players, $\mathrm{n}=11$ ) and WH-1, WH-2 (wheelchair players, $\mathrm{n}=9$ ). In control groups, disabled persons with inactive lifestyle (standing, $n=13$ and wheelchair, $n=10$ ) were included in the study. In order to identify the physical characteristics of the participants; stature, weight, BMI, upper extremity length (arm-forearm-hand), circumference (arm-forearm), flexibility, balance, modified sit-ups, modified abdominal endurance, hand grip strength, plate tapping and modified push-up tests were made. SPSS 21.0 program was used in the analysis of the data and differences between the groups were determined by Mann-Whitney U test. Significancy level was considered as $p<0.05$. In the result of the study, significant differences were determined according to control groups In the parameters of weight, BMI, balance, modified situps, hand grip strength, plate tapping and modified push-up parameters of female disabled badminton players playing standing and in the parameters of weight, BMI, flexibility, modified sit-ups, modified abdominal endurance, and plate tapping of wheelchair badminton players. As a result, it is determined that badminton sports improve the physical properties of physically handicapped women. In addition, it can be said that badminton sport can have a positive contribution in the process of raising the physical fitness levels of persons with disabilities who are deprived of some physical capacity and adaptation to life conditions.
\end{abstract}

Keywords: Para-badminton, physically disabilitiy, physical features.

\section{INTRODUCTION}

Sport is an important activity to get rid of the physical and mental stress of the individuals under the heavy burden of societal life, and to physically harmonize with the life conditions (11). It increases self-confidence of particularly handicapped individuals and removes the depression of being handicapped, thereby provides them to be more social, more sociable, and more successful in daily life $(4,7,12)$. Besides, the importance of sport and exercise, which are important means in prevention and rehabilitation of physical health problems that can arise in handicapped individuals, gets twofold important in individuals with limited physical activity due to physical disability. Today, as an indication of the importance attached to handicapped sport branches, it is observed that handicapped players have shown great development and earned great successes $(2,5,9,17)$.
One of the many sports branches adapted for the handicapped is badminton, which has a long history with its historical roots.

Being played by all age groups, badminton is one of the most popular sports in the world $(21,27)$. Being a contactless game and being among the Paralympic games of 2020 provided the quick spread of physically handicapped badminton. Especially SL-4 and SL-5 categories in handicapped badminton are fast and exciting sports having the same standards with normal badminton in terms of game rules and court size. Besides, wheelchair badminton is characterized with high intensity activities such as hits like clear, drive, and smash that necessitates high effort particular to badminton sport; high level ability to use the wheelchair; ability to make fast and sudden moves to front side and back side, and short sprints. In order to perform all 
of these abilities, the physical fitness level of the individual becomes vital.

The objective of this research is to determine the physical characteristics of the physically handicapped female badminton players and to examine the effects of badminton sport on physical development of physically handicapped females by comparing with handicapped individuals who do not deal with sports.

\section{MATERIALS \& METHODS}

Physically handicapped female badminton players $(n=20$, exercise age average; 4.2$)$ and control group that consist of physically handicapped $(n=23)$ volunteered in the research, 43 female badminton players in total.

Necessary allowances regarding the tests and measurements were received from the Federation Chairmanship, administrators and coaches of cities participating in the Physically Disabled Badminton Turkey Championship. Ethics Committee approval (Report No: 2017/1032) was obtained from the Necmettin Erbakan University Medical Faculty. All of the participators volunteering in the study signed the informed consent and personal data form.

According to the disability classification of the International Physically Disabled Badminton Federation, the players of the experiment group were classified in two groups: SL-3, SL-4, SU-5 (on foot, $\mathrm{n}=11$ ), and $\mathrm{WH}-1, \mathrm{WH}-2$ (on wheelchair, $\mathrm{n}=9$ ). SS-6 category (dwarfs) was not involved. Control group of the study was consisted of physically disabled individuals who did not deal with sports (on foot, $\mathrm{n}=13$; and on wheelchair, $\mathrm{n}=10$ ). Some constraints were applied considering the physical disability condition. Tests and measurements were applied on dominant hand and foot. Flamingo balance device was used for balance tests, but balance scores of the individuals on wheelchair were not recorded. Besides, modified push-up test scores of only 16 participators were determined since 3 individuals of the control group and 5 of the on-foot handicapped badminton players were amputee. Tests and protocols for determining the physical features of the participants were as follows.

\section{Tests Applied}

Height and Body weight: In the linear measurements a tapeline with $0.01 \mathrm{~m}$ sensitivity score was used. Weight measurements were made with a digital weighing scale with a sensitivity level of $0.01 \mathrm{~kg}(30)$.

Turk J Sport Exe 2018; 20(I): 1-8

๑ 2018 Faculty of Sport Sciences, Selcuk University
Body mass index: Using body weights and lengths, $\mathrm{BMI}$ was determined using the BMI = Body weight / (Length)2 formula (30).

Upper extremity length, arm length, forearm length, hand length, arm circumference and forearm circumference measurements were made with tape and recorded in $\mathrm{cm} .(6,16)$.

Upper extremity length: Determined by measuring the distance between the Acromion and the tip of the longest finger on the hand.

Arm length: Determined by measuring the distance between the acromion and the olecranon while the shoulder and the arm were loose.

Forearm length: Determined by measuring the distance between the olecranon and styloid protrusion of radius.

Hand length: Determined by measuring the distance between the styloid protrusion of radius and the tip of the longest finger on the hand.

Arm circumference: Determined by locating the middle point of the distance between the acromion and olecranon, and measured while the muscles were loose.

Forearm circumference: Determined by locating the most swollen point of the muscle, and measured while the arm was loose.

Sit and reach test: was determined on the sit and reach platform, and recorded in $\mathrm{cm}$ (10).

Balance measurement: Balance scores were determined with Flamingo Balance device. Test lasted for one minute and at the end of the time, each balance attempt of the subject was counted and recorded as the balance result (24).

Modified Sit-up Test: The player was positions lying on his back on the mat, knees bent, soles of the feet fully on the mat, hands on each side of the hips, and fingers in extension on the mat. The legs were supported as to keep the knees bent. The individual was asked for arising until the scapula bottom level, and do as many sit-ups as he could in 30 seconds $(18,22)$.

Modified abdominal endurance: Lying on his back on the mat, the individual was asked for arising until scapula bottom level and keep this position as much as he could. The time was stopped and recorded, as the participant touched the scapula bottom level or deformed the position (8). 
Hand Grasping Strength: Beginning from the right hand, the measurement was made with Jamar brand dynamometer and recorded in $\mathrm{kg}$, while the subject was on foot, arm straight with a $10-15^{\circ}$ angle from the shoulder on one side (10).

Plate tapping test: It was applied to measure the arm move speed. Two plastic discs (A and B) were placed on the table, $80 \mathrm{~cm}$ away from each other. Subject touched A, and B discs 25 times (totally 50) with the dominant hand as fast as possible. The timekeeper started as the subject touched $\operatorname{disc} \mathrm{A}$, and the value obtained at the end of the test was recorded in seconds (1).

\section{RESULTS}

Table 1. Average values of on foot disabled badminton players (1) and control group (2)

\begin{tabular}{|c|c|c|c|c|}
\hline VARIABLES & Group & $\mathrm{N}$ & Mean & S. D. \\
\hline \multirow{2}{*}{ Age } & 1 & 11 & 23.72 & 6.26 \\
\hline & 2 & 13 & 28.23 & 3.60 \\
\hline \multirow{2}{*}{ Training age } & 1 & 11 & 3.72 & 1.34 \\
\hline & 2 & 13 & 0.00 & 0.00 \\
\hline \multirow{2}{*}{ Height } & 1 & 11 & 163.81 & 3.40 \\
\hline & 2 & 13 & 160.53 & 3.55 \\
\hline \multirow{2}{*}{ Weight } & 1 & 11 & 56.09 & 3.70 \\
\hline & 2 & 13 & 63.30 & 7.46 \\
\hline \multirow{2}{*}{ BMI } & 1 & 11 & 20.92 & 1.63 \\
\hline & 2 & 13 & 24.49 & 2.07 \\
\hline \multirow{2}{*}{ Upper extremity length } & 1 & 11 & 76.54 & 1.98 \\
\hline & 2 & 13 & 77.42 & 1.55 \\
\hline \multirow{2}{*}{ Arm length } & 1 & 11 & 30.31 & 0.81 \\
\hline & 2 & 13 & 30.46 & 0.62 \\
\hline \multirow{2}{*}{ Forearm length } & 1 & 11 & 26.59 & 0.88 \\
\hline & 2 & 13 & 27.00 & 0.73 \\
\hline \multirow{2}{*}{ Hand length } & 1 & 11 & 19.63 & 1.16 \\
\hline & 2 & 13 & 19.96 & 1.14 \\
\hline \multirow{2}{*}{ Arm circumference } & 1 & 11 & 27.59 & 1.99 \\
\hline & 2 & 13 & 26.42 & 1.84 \\
\hline \multirow{2}{*}{ Forearm circumference } & 1 & 11 & 25.40 & 1.51 \\
\hline & 2 & 13 & 24.96 & 1.40 \\
\hline \multirow{2}{*}{ Flexibility } & 1 & 11 & 28.54 & 5.95 \\
\hline & 2 & 13 & 27.23 & 4.81 \\
\hline \multirow{2}{*}{ Balance } & 1 & 11 & 4.45 & 2.20 \\
\hline & 2 & 13 & 6.92 & 1.55 \\
\hline \multirow{2}{*}{ Modified sit-up } & 1 & 11 & 28.90 & 2.54 \\
\hline & 2 & 13 & 23.00 & 2.85 \\
\hline \multirow{2}{*}{ Modified abdominal endurance } & 1 & 11 & 91.54 & 19.94 \\
\hline & 2 & 13 & 80.84 & 22.90 \\
\hline \multirow{2}{*}{ Hand grasping strength } & 1 & 11 & 40.18 & 5.52 \\
\hline & 2 & 13 & 35.30 & 5.46 \\
\hline \multirow{2}{*}{ Plate tapping } & 1 & 11 & 11.90 & 1.35 \\
\hline & 2 & 13 & 13.12 & 1.44 \\
\hline \multirow{2}{*}{ Modified push up } & 1 & 6 & 25.16 & 3.97 \\
\hline & 2 & 10 & 19.80 & 4.93 \\
\hline
\end{tabular}


Table 2. Mann Whitney U analysis results of on foot disabled badminton players (1) and control group (2)

\begin{tabular}{|c|c|c|c|c|c|}
\hline VARIABLES & Group & $\mathrm{N}$ & Mean Rank & $\mathrm{U}$ & $p$ \\
\hline \multirow{2}{*}{ Age } & 1 & 11 & 9.45 & \multirow{2}{*}{38.000} & \multirow{2}{*}{0.051} \\
\hline & 2 & 13 & 15.08 & & \\
\hline \multirow{2}{*}{ Height } & 1 & 11 & 15.50 & \multirow{2}{*}{38.500} & \multirow{2}{*}{0.052} \\
\hline & 2 & 13 & 9.96 & & \\
\hline \multirow{2}{*}{ Weight } & 1 & 11 & 8.77 & \multirow{2}{*}{30.500} & \multirow{2}{*}{$0.017^{*}$} \\
\hline & 2 & 13 & 15.65 & & \\
\hline \multirow{2}{*}{ BMI } & 1 & 11 & 7.32 & \multirow{2}{*}{14.500} & \multirow{2}{*}{$0.001^{*}$} \\
\hline & 2 & 13 & 16.88 & & \\
\hline \multirow{2}{*}{ Upper extremity length } & 1 & 11 & 10.50 & \multirow{2}{*}{49.500} & \multirow{2}{*}{0.199} \\
\hline & 2 & 13 & 14.19 & & \\
\hline \multirow{2}{*}{ Arm length } & 1 & 11 & 11.86 & \multirow{2}{*}{64.500} & \multirow{2}{*}{0.678} \\
\hline & 2 & 13 & 13.04 & & \\
\hline \multirow{2}{*}{ Forearm length } & 1 & 11 & 10.73 & \multirow{2}{*}{52.000} & \multirow{2}{*}{0.250} \\
\hline & 2 & 13 & 14.00 & & \\
\hline \multirow{2}{*}{ Hand length } & 1 & 11 & 11.41 & \multirow{2}{*}{59.500} & \multirow{2}{*}{0.483} \\
\hline & 2 & 13 & 13.42 & & \\
\hline \multirow{2}{*}{ Arm circumference } & 1 & 11 & 15.41 & \multirow{2}{*}{39.500} & \multirow{2}{*}{0.062} \\
\hline & 2 & 13 & 10.04 & & \\
\hline \multirow{2}{*}{ Forearm circumference } & 1 & 11 & 14.09 & \multirow{2}{*}{54.000} & 0005 \\
\hline & 2 & 13 & 11.15 & & 0.000 \\
\hline Flexibility & 1 & 11 & 13.50 & 60.500 & 0.523 \\
\hline & 2 & 13 & 11.65 & & \\
\hline Balance & 1 & 11 & 8.41 & 26500 & 0008 \\
\hline Balance & 2 & 13 & 15.96 & 26.500 & 0.008 \\
\hline Modifind cit un & 1 & 11 & 17.95 & 11500 & 0000 \\
\hline Modifled sit-up & 2 & 13 & 7.88 & 11.500 & 0.000 \\
\hline Modified abdominalondurance & 1 & 11 & 14.55 & 49000 & 0192 \\
\hline 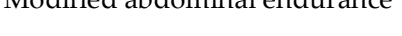 & 2 & 13 & 10.77 & 49.000 & 0.192 \\
\hline Hond ononino thonth & 1 & 11 & 16.14 & 21500 & $0020 *$ \\
\hline Hand grasping strength & 2 & 13 & 9.42 & 31.500 & $0.020^{\circ}>25$ \\
\hline Plato tanning & 1 & 11 & 9.27 & 36000 & $0040 *$ \\
\hline Plate tapping & 2 & 13 & 15.23 & 36.000 & $0.040^{x}$ \\
\hline Modified nuch un & 1 & 6 & 11.58 & 11500 & $0044 *$ \\
\hline Niodmled pusn up & 2 & 10 & 6.65 & 11.000 & $0.044^{\prime}$ \\
\hline
\end{tabular}

$\mathrm{p}<0.05$

When Table 2 is examined, it was determined that there was a statistically significant difference between experiment and control groups with regards to body weight $(\mathrm{U}=30.500, \mathrm{p}<0.05)$, BMI $(\mathrm{U}=14.500, \mathrm{p}<0.05)$, flamingo balance $(\mathrm{U}=26.500$, $\mathrm{p}<0.05)$, modified sit-ups $(\mathrm{U}=11.500, \mathrm{p}<0.05)$, hand

Table 3. Average values of on wheelchair disabled badminton players (1) and control group (2)

\begin{tabular}{lcccc}
\hline VARIABLES & Group & $\mathrm{N}$ & Mean & S. D. \\
\hline \multirow{2}{*}{ Age } & 1 & 9 & 35.22 & 8.88 \\
\hline \multirow{2}{*}{ Training age } & 2 & 10 & 32.20 & 6.37 \\
\hline \multirow{2}{*}{ Height } & 1 & 9 & 4.77 & 3.07 \\
\hline \multirow{2}{*}{ Weight } & 2 & 10 & 0.00 & 0.00 \\
\hline \multirow{2}{*}{ BMI } & 2 & 9 & 157.55 & 8.90 \\
\hline \multirow{2}{*}{ Upper extremity length } & 1 & 10 & 159.40 & 9.94 \\
\hline \multirow{2}{*}{ Arm length } & 1 & 9 & 53.11 & 6.03 \\
\hline Forearm length & 2 & 10 & 60.20 & 5.32 \\
\cline { 2 - 5 } & 2 & 9 & 21.64 & 2.15 \\
\hline
\end{tabular}

Turk J Sport Exe 2018; 20(I): 1-8

(4) 2018 Faculty of Sport Sciences, Selcuk University grasping power $(\mathrm{U}=31.500$, $\mathrm{p}<0.05)$, disc touching test $(\mathrm{U}=36.000, \mathrm{p}<0.05)$ and modified push-up $(\mathrm{U}=11.500, \mathrm{p}<0.05)$ parameters, while it was determined that there was no difference with regards to other parameter. 


\begin{tabular}{|c|c|c|c|c|}
\hline & 2 & 10 & 25.00 & 0.74 \\
\hline \multirow{2}{*}{ Hand length } & 1 & 9 & 18.55 & 0.84 \\
\hline & 2 & 10 & 19.10 & 0.94 \\
\hline \multirow{2}{*}{ Arm circumference } & 1 & 9 & 29.27 & 2.63 \\
\hline & 2 & 10 & 28.40 & 2.15 \\
\hline \multirow{2}{*}{ Forearm circumference } & 1 & 9 & 25.55 & 1.66 \\
\hline & 2 & 10 & 24.60 & 1.39 \\
\hline \multirow{2}{*}{ Flexibility } & 1 & 9 & 36.11 & 4.80 \\
\hline & 2 & 10 & 30.10 & 3.14 \\
\hline \multirow{2}{*}{ Modified sit-up } & 1 & 9 & 24.00 & 3.67 \\
\hline & 2 & 10 & 20.60 & 2.63 \\
\hline \multirow{2}{*}{ Modified abdominal endurance } & 1 & 9 & 96.66 & 24.93 \\
\hline & 2 & 10 & 75.60 & 17.10 \\
\hline \multirow{2}{*}{ Hand grasping strength } & 1 & 9 & 37.88 & 5.08 \\
\hline & 2 & 10 & 39.20 & 4.41 \\
\hline \multirow{2}{*}{ Plate tapping } & 1 & 9 & 11.94 & 1.35 \\
\hline & 2 & 10 & 13.87 & 1.31 \\
\hline \multirow{2}{*}{ Modified push up } & 1 & 9 & 19.22 & 4.91 \\
\hline & 2 & 10 & 20.40 & 4.14 \\
\hline
\end{tabular}

Table 4. Mann Whitney U analysis results of on wheelchair disabled badminton players (1) and control group (2)

\begin{tabular}{|c|c|c|c|c|c|}
\hline VARIABLES & Group & $\mathrm{N}$ & Mean Rank & $\mathrm{U}$ & $\mathrm{p}$ \\
\hline \multirow{2}{*}{ Age } & 1 & 9 & 11.00 & \multirow{2}{*}{36.000} & \multirow{2}{*}{0.462} \\
\hline & 2 & 10 & 9.10 & & \\
\hline \multirow{2}{*}{ Height } & 1 & 9 & 7.94 & \multirow{2}{*}{26.500} & \multirow{2}{*}{0.130} \\
\hline & 2 & 10 & 11.85 & & \\
\hline \multirow{2}{*}{ Weight } & 1 & 9 & 6.67 & \multirow{2}{*}{15.000} & \multirow{2}{*}{$0.014^{*}$} \\
\hline & 2 & 10 & 13.00 & & \\
\hline \multirow{2}{*}{ BMI } & 1 & 9 & 6.89 & \multirow{2}{*}{17.000} & \multirow{2}{*}{$0.022^{*}$} \\
\hline & 2 & 10 & 12.80 & & \\
\hline \multirow{2}{*}{ Upper extremity length } & 1 & 9 & 8.33 & \multirow{2}{*}{30.000} & \multirow{2}{*}{0.219} \\
\hline & 2 & 10 & 11.50 & & \\
\hline \multirow{2}{*}{ Arm length } & 1 & 9 & 8.78 & \multirow{2}{*}{34.000} & \multirow{2}{*}{0.363} \\
\hline & 2 & 10 & 11.10 & & \\
\hline \multirow{2}{*}{ Forearm length } & 1 & 9 & 7.89 & \multirow{2}{*}{26.000} & \multirow{2}{*}{0.117} \\
\hline & 2 & 10 & 11.90 & & \\
\hline \multirow{2}{*}{ Hand length } & 1 & 9 & 8.06 & \multirow{2}{*}{27.500} & \multirow{2}{*}{0.147} \\
\hline & 2 & 10 & 11.75 & & \\
\hline \multirow{2}{*}{ Arm circumference } & 1 & 9 & 11.06 & \multirow{2}{*}{35.500} & \multirow{2}{*}{0.436} \\
\hline & 2 & 10 & 9.05 & & \\
\hline \multirow{2}{*}{ Forearm circumference } & 1 & 9 & 12.33 & \multirow{2}{*}{24.000} & \multirow{2}{*}{0.080} \\
\hline & 2 & 10 & 7.90 & & \\
\hline & 1 & 9 & 13.89 & & \\
\hline Flexibility & 2 & 10 & 6.50 & 10.000 & $0.004^{*}$ \\
\hline & 1 & 9 & 13.06 & & \\
\hline Modified sit-up & 2 & 10 & 7.25 & 17.500 & $0.023^{*}$ \\
\hline Modified ahdominal ondurance & 1 & 9 & 12.72 & 20500 & $0045 *$ \\
\hline Moditied abdominal endurance & 2 & 10 & 7.55 & 20.500 & $0.04 b^{n}$ \\
\hline & 1 & 9 & 8.94 & & \\
\hline Hand grasping strength & 2 & 10 & 10.95 & 35.500 & 0.436 \\
\hline & 1 & 9 & 6.56 & 14000 & \\
\hline Plate tapping & 2 & 10 & 13.10 & 14.000 & $0.011^{*}$ \\
\hline Modified nush un & 1 & 9 & 8.94 & 35500 & 0.436 \\
\hline Moditied push up & 2 & 10 & 10.95 & 35.500 & 0.436 \\
\hline
\end{tabular}

${ }^{*} \mathrm{p}<0.05$

When Table 4 is examined, it was determined that there was a statistically significant difference between experiment and control groups with regards to body weight $(\mathrm{U}=15.000, \mathrm{p}<0.05)$, BMI $(\mathrm{U}=17.000, \mathrm{p}<0.05)$, flexibility $(\mathrm{U}=10.000, \mathrm{p}<0.05)$, modified sit-ups $(\mathrm{U}=17.500, \mathrm{p}<0.05)$, modified abdominal endurance $(\mathrm{U}=20.500, \mathrm{p}<0.05)$ and disc touching test $(\mathrm{U}=36.000, \mathrm{p}<0.05)$ parameters, while it was determined that there was no difference with regards to other parameters. 


\section{DISCUSSION}

Objective of this research is to determine the physical features of physically handicapped female badminton players, and to examine the effects of badminton sport on physical development of physically handicapped individuals by making a comparison with the handicapped individuals who did not deal with sport.

It was observed that the values of badminton players on foot and on wheelchair, and the values of disabled individuals not dealing with sport were similar in anthropometric measurements. However, it was determined that badminton players both on foot and wheelchair have lower body weight and lower BMI values, and that there were statistically significant differences. This result is considered as an effect of the exercises. Moreover, it was observed that balance, modified sit-up, hand grasping power, disc touching test, and modified push-up values of the badminton players on foot, and flexibility, modified sit-up, modified abdominal endurance, and disc touching test values of the badminton players on wheelchair were statistically significantly better compared to the individuals without sport activity.

It was reported that sport is vital for handicapped rehabilitation in gaining balance, muscle control, freedom in movements, and coordination (8). Silfies et al. (20) mentioned that core stability has the ability to control the movement and position of the body during the functional activity. Kale (14) mentioned that coordinative abilities are important in badminton sport. The high results of balance, strength and arm move speed performances in the study are supporting the given literature findings. Tolfrey et al. (23) reported that cardiovascular endurance levels of the wheelchair players were related with body mass, adipose tissue, and body control. It was determined in the study that abdominal strength and abdominal endurance values of the badminton players both on foot and on wheelchair were statistically significantly in better level. In a similar study on amputee football players, positive correlation was determined between upper body muscle stabilization and upper body flexor muscle power, and it was reported that upper body stabilization, balance and upper body muscle power exercises must be included in exercise programs (3).

It was determined that flexibility averages of the badminton players on wheelchair were statistically significantly higher compared to the individuals without any sport activity, while there was no difference with regards to the badminton players on foot. This result could be originated from that badminton players on foot particularly did not have enough flexibility improving practices in their exercises. In badminton sport branch, flexibility of upper body muscles, upper and lower extremity provides numerous advantages for the player. Flexibility of the muscles and joint movement variety play vital role particularly in difficult positions like over-head hits that a player needs during a rally and while doing a technique movement. Therefore, it is a necessity to include sufficient flexibility improving practices in exercise programs. In other studies on physically disabled individuals, it was mentioned that upper body and extremity muscles shoulder significant burden during daily activities particularly like pushing the wheelchair, over repetition, and transfer; thus the power of the upper extremities was also important $(15,19,25,26)$. When the findings of the study are examined, it can be similarly mentioned that badminton sport is important for particularly physically handicapped individuals in development of the upper body and upper extremity muscles. Besides, it is an anticipated result that the hand grasping power values of the badminton players on foot were determined to be statistically significant compared to the handicapped individuals without any sport activity. It is considered to be the result of special hand grasping power enhancing practices, since hand grasping power is vital in many parts of the game, and due to the necessity to grasp the racquet tighter in some technique hits (drive, netkill, smash). However no statistically significant difference was observed between badminton players on wheelchair and the handicapped control group. This situation can be explained with high hand grasping power values as a natural result of daily activities such as pushing the wheelchair and daily transfer.

Moving in complete independency is vital for a physically handicapped individual. When disabled individuals who deal or do not deal with sports are compared, it is observed that the ones dealing with sports are more independent in terms of mobility, have higher social participation, and have higher life quality compared to individuals who do not deal with sports, and that regular exercises of an individual were effective on physical fitness $(13,28$, 29). 
The strength of this study is that it is the first research comparing the physical features of female badminton players on foot and wheelchair, and that obtaining some findings. However, it is imperative to explain an important point about the method of our study. Handicapped badminton players both on foot and on wheelchair do not form a homogenous group. These individuals have pathologies differentiating their functional levels. Their functional characteristics may differ even if they have the same disability. In this context, classifying

\section{REFERENCES}

1. Adam C. Eurofit: handbook for the Eurofit tests of physical fitness Rome: Italian National Olympic Committee, Central.

2. Direction for Sport's Technical Activities Documentation and Information Division, 1988.

3. Auxter D, Pyfer J, Huettig C. Principles and Methods of Adapted Physical Education and Recreation. 9th ed, New York: McGraw Hill, 2001.

4. Aytar A, Pekyavas NO, Ergun N, Karatas M. Is there a relationship between core stability, balance and strength in amputee soccer players? A pilot study. Prosthet Orthot Int. 2012; 36(3): 332-338.

5. Cooper RA, Quatrano LA, Axelson PW, Harlan W, Stineman M, Franklin B, Krause JS, Bach J, Chambers H, Chao EY, Alexander M, Painter P. Research on physical activity and health among people with disabilities: A consensus statement. J of Rehabil Res Dev, 1999; 36(2): 142-154.

6. Devillard X, Rimaud D, Roche F, Calmels P. Effect of training programs for spinal cord injury. Annales de Readaptation et de Medecine Physique, 2007; 50(6): 490-498.

7. Easterby R, Kroemer KHE, Chaffin DB. Anthropometry and Biomechanics. New York and London: Plenum Press, 1982.

8. Ergun N, Baltacı G. Spor Yaralanmalarında Fizyoterapi ve Rehabilitasyon Prensipleri. Ankara: Pelikan Yayınevi, 2014.

9. Ergun N, Baltacı G. Spor Yaralanmalarında Fiztoyetrapi ve Rehabilitasyon Prensipleri (2. bs.). Ankara: Hacettepe Üniversitesi Fizik Tedavi ve Rehabilitasyon Yüksekokulu Yayınları, 2006.

10. Giacobbi PR, Stancil M, Hardin B, Bryant L. Physical activity and quality of life experienced by highly active individuals with physical disabilities. APAQ, 2008; (25)3: 189-207.

11. Günay M, Tamer K, Cicioğlu İ. Spor Fizyolojisi ve Performans Ölçümü. (3. Bask1). Ankara: Gazi Kitabevi, 2013.

12. Gür A. Özürlülerin Sosyal Yasama Uyum Süreçlerinde Sportif Etkinliklerin Rolü. Ankara: T.C. Başbakanlık Özürlüler Dairesi Başkanlığı Yayınları, 2001.

13. Hutzler Y, Chacham-Guber A, Reiter S. Psychosocial effects of reverse-integrated basketball activity compared to separate and no physical activity in young people with physical disability. Res Dev Disabil, 2013; 34(1): 579-587.

14. Hutzler Y, Ochana S, Bolotin R, Kalina E. Aerobic and anaerobic arm-cranking power outputs of males with lower limb impairments: relationship with sport participation the physically disabled badminton players as on foot and on wheelchair can be accepted as the weakness of the study.

Consequently, it is determined that badminton sport improves the physical features of physically handicapped females. Additionally, it can be mentioned that badminton sport can have a positive contribution in the process of raising the physical fitness levels of individuals with disabilities who are deprived of some physical capacity and adaptation to life conditions.

intensity, age, 1mpairment and functional classification. SpinalCord, 1998; (36)3: 205-212.

15. Kale R. Okullarda ve Kulüplerde Badminton. Ankara: Nobel Yayıncilık, 2011.

16. Kulig K, Newsam CJ, Mulroy SJ, Rao S, Gronley JK, Bontrager EL, Perry J. The effect of level of spinal cord injury on shoulder joint kinetics during manual wheelchair propulsion. Clin Biomech, 2001; 16(9): 744-751.

17. Otman AS, Demirel H, Sade A. Tedavi Hareketlerinde Temel Değerlendirme Prensipleri. Hacettepe Üniversitesi Fizik Tedavi ve Rehabilitasyon Yüksekokulu Yayınları, 1995.

18. Özdemir G, Ersoy G. Engelli sporcularda beslenme, sağlık ve performans etkileşimi. Türk Fizik Tıp Rehabilitasyon Dergisi, 2009; 55: 116-121.

19. Sahlberg ME, Svantesson U, Thomas EM, Strandvik B. Muscular strength and function in patients with cystic fibrosis. Chest, 2005; 127(5): 1587-1592.

20. Samuelsson KA, Tropp H, Gerdle B. Sholder pain and its consequences in paraplegic spinal cord-injured, wheelchair users. Spinal Cord, 2004; 42(1): 41-46.

21. Silfies SP, Ebaugh D, Pontillo M, Butowicz CM. Critical review of the impact of core stability on upper extremity athletic injury and performance. Braz J Phys Ther, 2015; 19(5): 360-368.

22. Sucharitha BS, Reddy AV, Madhavi K. Effectiveness of plyometric training on anaerobic power and agility in female badminton players. International Journal of Pharmaceutical Research And Bio-Science, 2014; 3(4): 754-761.

23. Tomchuk D. Companion Guide to Measurement and Evaluation for Kinesiology, Chapter 4, Local Muscular Endurance Testing, 2010.

24. Tolfrey VL, Batterham AM, Tolfrey K. Scaling behavior of VO2 peak in trained wheelchair athletes. Med. Sci. Sports Exerc, 2003; 35(12): 2106-2111.

25. Tsigilis N, Douda H, Tokmakidis SP. Test-retest reliability of the eurofit test battery administered to university students. Perceptual and Motor Skills, 2002; 95(3): 1295-1300.

26. Van Drongelen S, De Groot S, Veeger HE, Angenot EL, Dallmeijer AJ, Post MW, Woude LH. Upper extremity musculoskeletal pain during and after rehabilitation in 
wheelchair-using persons with a spinal cord injury. Spinal Cord, 2006; 44(3): 152-159.

27. Veeger HEJ, Rozendaal LA, Van der Helm FCT. Load on the shoulder in low intensity wheelchair propulsion. Clin Biomech, 2002; 17: 211-218.

28. Vicen JA, Del Coso J, Millan CG, Salinero JJ, Abian P. Analysis of dehydration and strength in elite badminton players. Plos One Journal, 2012; 7(5): 1-8.

29. Wilhite B, Shank J. In praise of sport: promoting sport participation as a mechanism of health among persons with a disability. Disabil Health J, 2009; 2(3): 116-127.

30. Yazıcıŏ̆lu K, Yavuz F, Göktepe AS, Tan AK. Influence of adapted sports on quality of life and life satisfaction in sport participants and non-sport participants with physical disabilities. Disabil Health J, 2012; 5(4): 249-253. 